\title{
Use of Flow-Duration Curves to Evaluate Effects of Urbanization on Streamflow Patterns on \\ Long Island, New York
}

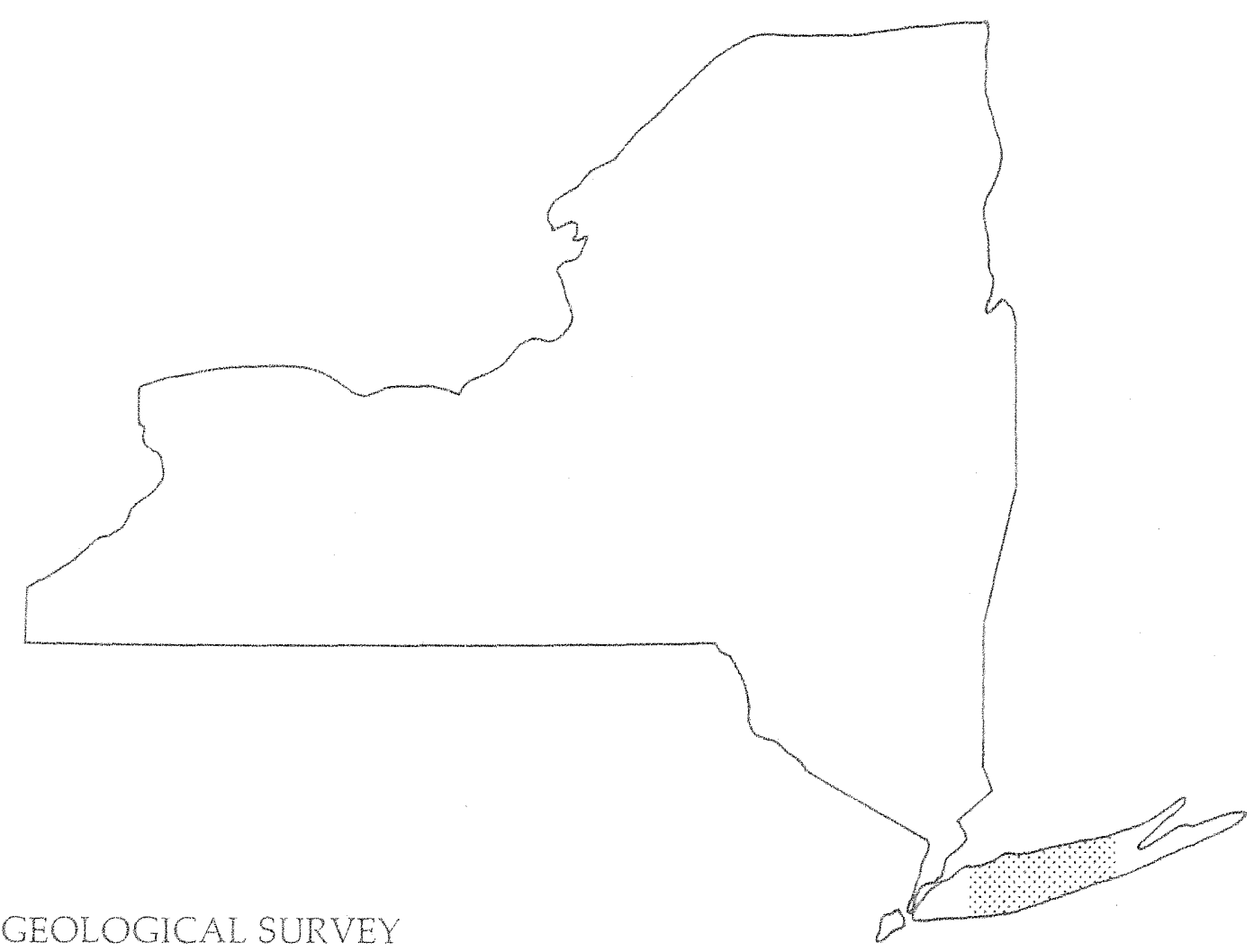

\section{U.S. GEOLOGICAL SURVEY}

Water-Resources Investigations 80-114

prepares in cooperation with the

Nassau County Deparment of Public Works

Sulok Couny Deparment of Heath Services

Sutrolk Couny Water Authonity

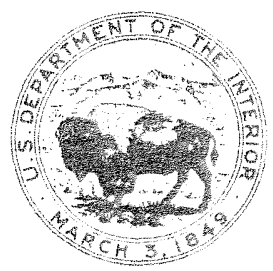




\begin{tabular}{|c|c|c|}
\hline $\begin{array}{l}\text { REPORT DOCUMENTATION } \\
\text { PAGE }\end{array}$ & 1. REPORT NO. & 3. Recipient's Accession No. \\
\hline \multirow{2}{*}{\multicolumn{2}{|c|}{$\begin{array}{l}\text { 4. Title and subtitle } \\
\text { USE OF FLOW-DURATION CURVES TO EVALUATE EFEECTS OF } \\
\text { URBANIZATION ON STREAMFLOW PATTERNS ON LONG ISLAND, NEW YORK }\end{array}$}} & $\begin{array}{l}\text { 5. Report Date } \\
1981\end{array}$ \\
\hline & & 6. \\
\hline \multicolumn{3}{|c|}{$\begin{array}{l}\text { 7. Author(s) } \\
\text { Keith R. Prince }\end{array}$} \\
\hline \multicolumn{2}{|c|}{$\begin{array}{l}\text { 9erforming Organization Name and Address } \\
\text { U.S. Geological Survey } \\
\text { Water Resources Division } \\
343 \text { U. S. Post Office \& Courthouse } \\
\text { Albany, New York } 12201\end{array}$} & $\begin{array}{l}\text { 10. Project/Task/Work Unit No. } \\
\text { 11. Contract(C) or Grant(G) No. } \\
\text { (C) } \\
\text { (G) }\end{array}$ \\
\hline \multirow{2}{*}{\multicolumn{2}{|c|}{$\begin{array}{l}\text { 12. Sponsoring Organization Name and Address } \\
\text { U.S. Geological Survey } \\
\text { Water Resources Division } \\
343 \text { U. S. Post Office \& Courthouse } \\
\text { Albany, New York } 12201\end{array}$}} & 13. Type of Report \& Period Covered \\
\hline & & 14. \\
\hline
\end{tabular}

15. Supplementary Notes

Prepared in cooperation with the Nassau County Department of Public Works, Suffolk County Department of Health Services, Suffolk County Water Authority

16. Abstract (Limit: 200 words)

Streamflow patterns on Long Island have been changing over the last three decades in response to eastward population growth and urbanization. Flow-duration curves for nine streams in Nassau and Suffolk Counties indicate that during this time, streams in urbanized areas have had increased peak flows and decreased base flows, whereas streams in sparsely populated areas have shown little or no change. The increase in peak flows reflects the greater volume of storm runoff from impermeable surfaces such as roads, parking lots, and roofs. The decrease in base flow results from the lowering of ground-water levels, principally by sanitary sewerage and extensive pumping, for nublic water supply.

At East Meadow Brook, in a sewered, densely populated area of Nassau County, peak flows (1-percent duration) increased by 41 percent during 1946-74, and base flows (98-percent duration) decreased by 99 percent. In contrast, peak and base flows of Carmans River, in a largely undisturbed, rural area of Suffolk County, showed fluctuations no greater than 19 percent during the same period.

17. Document Analysis a. Descriptors

* Streamflow, *Flow duration, *Urbanization, Baseflow runoff, Sewerage, Population, New York

b. Identifiers/Open-Ended Terms

Long Island, Streamflow patterns, Peak flow

c. COSATI Field/Group

\begin{tabular}{|c|c|c|c|}
\hline \multicolumn{2}{|c|}{ 18. Availability Statement } & $\begin{array}{l}\text { 19. Security Class (This Report) } \\
\text { Unclassified }\end{array}$ & $\begin{array}{l}\text { 21. No. of Pages } \\
24\end{array}$ \\
\hline \multicolumn{2}{|r|}{ No restriction on distribution } & $\begin{array}{l}\text { 20. Security Class (This Page) } \\
\text { Unclassified }\end{array}$ & 22. Price \\
\hline
\end{tabular}


USE OF FLOW-DURATION CURVES TO EVALUATE

EFFECTS OF URBANIZATION ON STREAMFLOW

PATTERNS ON LONG ISLAND, NEW YORK

by Keith R. Prince

U.S. GEOLOGICAL SURVEY

Water Resources Investigations 80-114

Prepared in cooperation with the

Nassau County Department of Public Works

Suffolk County Department of Health Services

Suffolk County Water Authority

Syosset, New York

1981

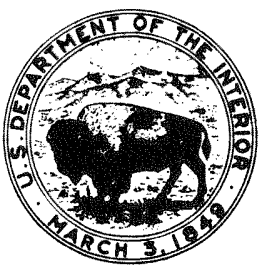


UNITED STATES DEPARTMENT OF THE INTERIOR

JAMES G. WATT, Secretary

GEOLOGICAL SURVEY

Doyle G. Frederick, Acting Director

For additional information write to:

U.S. Geological Survey

5 Aerial Way

Syosset, New York 11791 
Page

Conversion factors and abbreviations. . . . . . . . . . . . iv

Abstract. . . . . . . . . . . . . . . . . . . . 1

Introduction. . . . . . . . . . . . . . . . . . . . . . 1

Purpose and scope...................... . . . . . 2

Hydrologic environment. . . . . . . . . . . . . . . . . . . 3

Precipitation. . . . . . . . . . . . . . . . . . 3

Hydrogeology ........................ 3

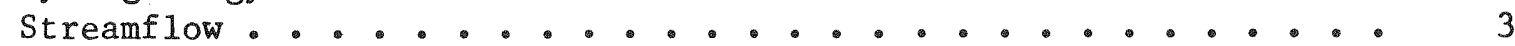

Urbanization. . . . . . . . . . . . . . . . . . 4

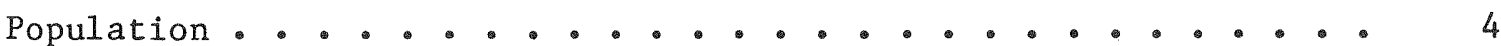

Aquifer recharge ...................... 8

Method of streamflow analysis .............. 8

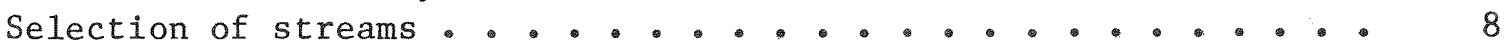

Flow-duration curves ................................. 10

Results . . . . . . . . . . . . . . ...... 14

Summary and conclusions . . . . . . . . . . . . . . 15

References cited.......................... 18

\section{ILLUSTRATIONS}

Page

Figure 1. Map showing location of major geographic features and

streams studied.......................

2. Graphs showing population density of selected towns and

municipalities in Nassau and Suffolk Counties, 1920-77...

3. Graph of annual precipitation at Mineola and Riverhead, 1940-75. ......................

4. Duration curves of daily flow, 1946-50 and 1970-74

A. Glen Cove Creek at Glen Cove.......... 11

B. Pines Brook at Malverne ............ 11

C. East Meadow Brook at Freeport . . . . . . . . 11

D. Mill Neck Creek at Mill Neck. .......... 12

E. Sampawams Creek at Babylon........... 12

F. Massapequa Creek at Massapequa......... 12

G. Nissequogue River near Smithtown.......... 13

H. Carmans River at Yaphank............ 13

I. Connetquot River near Oakdale.......... 13 


\section{TABLES}

Page

Table 1. Generalized description of geologic and hydrogeologic units.

2. Population density in Nassau and Suffolk Counties, 1950 and

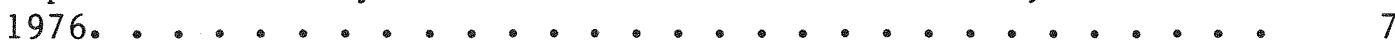

3. Stream discharge and percentage change, 1946-50 to 1970-74. 16

4. Changes in stream discharge and population density in surrounding communities, Nassau and Suffolk Counties, 1946-74 . . . . . . . . . . . . . . . . .

\section{CONVERSION FACTORS AND ABBREVIATIONS}

The following factors may be used to convert the inch-pound system of measurement in this report to the International System of units (metric system).

\begin{tabular}{|c|c|c|}
\hline Multiply & by & To obtain \\
\hline inches (in) & 25.4 & millimeters (mm) \\
\hline & 2.54 & centimeters $(\mathrm{cm})$ \\
\hline feet $(f t)$ & .3048 & meters (m) \\
\hline miles (mi) & 1.609 & kilometers $(\mathrm{km})$ \\
\hline square miles (mi2) & 2.590 & square kilometers $(\mathrm{km} 2)$ \\
\hline acres & .4049 & hectares (ha) \\
\hline feet per mile ( $\mathrm{ft} / \mathrm{mi})$ & .1894 & meters per kilometer $(\mathrm{m} / \mathrm{km})$ \\
\hline $\begin{array}{c}\text { cubic feet per second } \\
(\mathrm{ft} 3 / \mathrm{s})\end{array}$ & 28.32 & liters per second (L/s) \\
\hline & .02832 & $\begin{array}{c}\text { cubic meters per second } \\
(\mathrm{m} 3 / \mathrm{s})\end{array}$ \\
\hline $\begin{array}{c}\text { million gallons per day } \\
(\mathrm{Mgal} / \mathrm{d})\end{array}$ & .0438 & $\begin{array}{c}\text { cubic meters per second } \\
(\mathrm{m} 3 / \mathrm{s})\end{array}$ \\
\hline
\end{tabular}




\title{
USE OF FLOW-DURATION CURVES TO EVALUATE EFFECTS \\ OF URBANIZATION ON STREAMFLOW PATTERNS \\ ON LONG ISLAND, NEW YORK
}

\author{
By
}

Keith R. Prince

\begin{abstract}
Streamflow patterns on Long Island have been changing over the last three decades in response to eastward population growth and urbanization. Flowduration curves for nine streams in Nassau and Suffolk Counties indicate that, during this time, streams in urbanized areas have had increased peak flows and decreased base flows, whereas streams in sparsely populated areas have shown little or no change. The increase in peak flows reflects the greater volume of storm runoff from impermeable surfaces such as roads, parking lots, and roofs. The decrease in base flows results from the lowering of ground-water levels. principally by sanitary sewerage and extensive pumping for public water supply.

At East Meadow Brook, in a sewered, densely populated area of Nassau County, peak flows (1-percent duration) increased by 41 percent during 1946-74, and base flows (98-percent duration) decreased by 99 percent. In contrast. peak and base flows of Carmans River, in a largely undisturbed, rural area of Suffolk County, showed fluctuations no greater than 19 percent during the same period.
\end{abstract}

\section{INTRODUCTION}

Long Island has experienced rapid eastward urbanization since the $1930^{\circ} \mathrm{s}$ : this trend reached a peak in Nassau County in the $1950^{\circ} \mathrm{s}$ and early $1960^{\prime} \mathrm{s}$ and has gradually spread into Suffolk County (fig. 1). The sole source of fresh water for the residents of these two counties is ground water. In an effort to. protect the high quality of ground water from continued cesspool and septictank contamination, sanitary sewers have been installed in areas of dense population. However, these sewer systems have reduced recharge to aquifers, causing a general lowering of ground-water levels, which in turn has decreased the amount of ground-water discharge to streams.

The effects of urbanization on ground-water levels and streamflow on Long Island have been we11 documented in recent years (Franke, 1968; Garber and. Sulam, 1976; and Sulam, 1979). Several studies have determined the amount by which sanitary sewers have reduced or will reduce streamflow on Long Island (Kimmel and Harbaugh, 1975, 1976; Kimmel and others, 1977; Pluhowski and Spinello, 1978); but no studies of changes in streamflow regime in areas of increasing population density without sanitary sewers have been published. 
Urbanized unsewered areas have been considered by some to represent a relatively natural hydrologic environment, in that no water is lost from the ground-water reservoir through sewers. However, urbanization disturbs the hydrologic system in other ways; for example, the increase in impervious surfaces such as roads, roofs, parking lots, and sidewalks decreases the area available for infiltration of precipitation, and runoff is diverted to streams and coastal waters through storm sewers. At the same time, consumptive ground-water use increases with population and industrial growth so that demand increases while the supply gradually diminishes.

\section{Purpose and Scope}

This study investigates the changes in streamflow patterns in Nassau and Suffolk Counties since the 1940's and presents flow-duration curves to illustrate the impact of urbanization on streamflow. The streams studied represent three types of areas--urban and suburban with sewers, suburban without sewers, and rural without sewers. The data on streams within each area reveal changes in flow patterns of individual streams from 1946 to 1974 and allow comparison of these changes among the different areas represented. The location of the nine streams investigated and major features of the area are shown in figure 1.

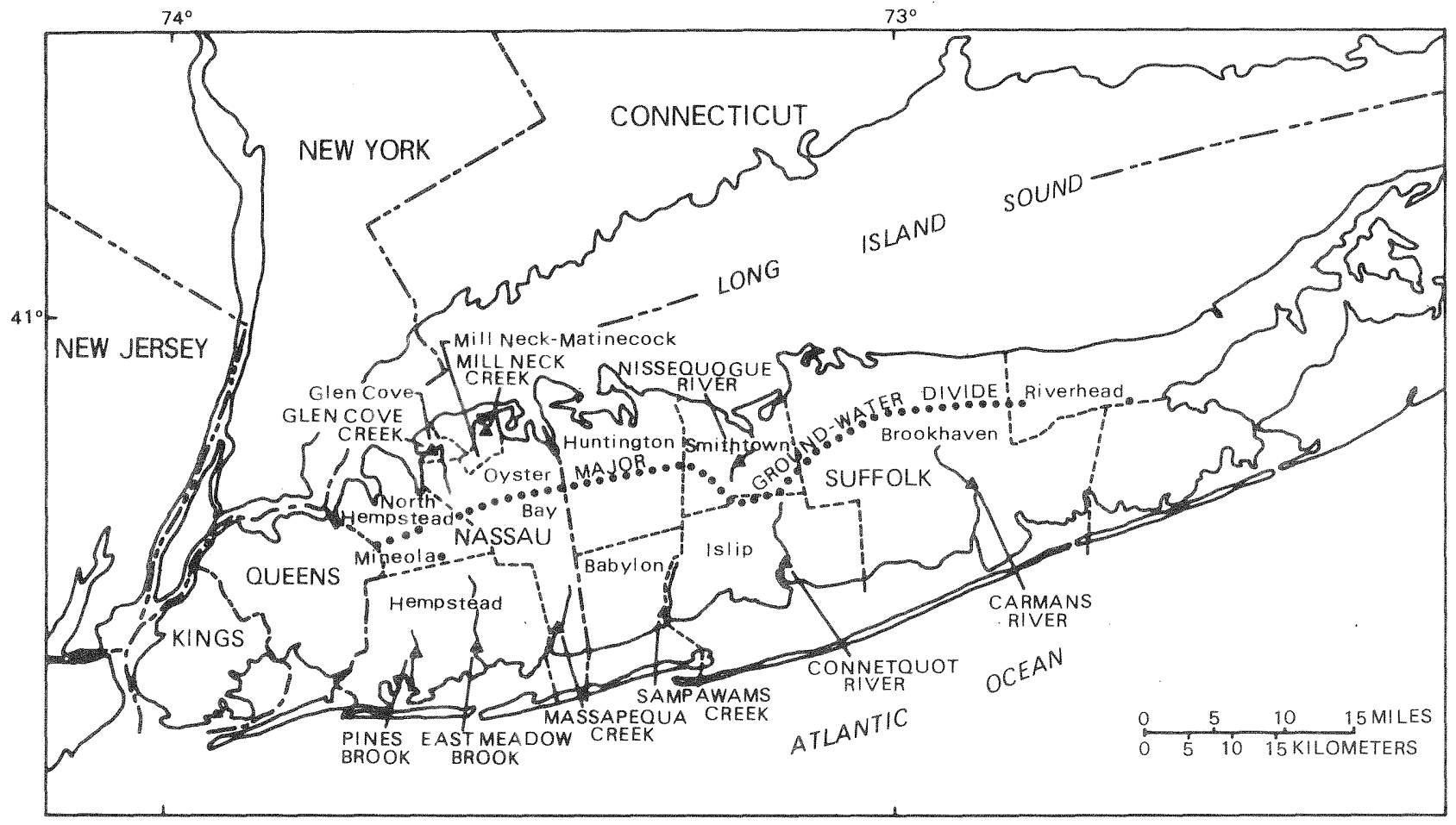

Figure 1.-Location of major geographic features and streams studied. 


\section{HYDROLOGIC ENVIRONMENT}

\section{Pracipitation}

Long Island's fresh-water supply is replenished solely by precipitation directly on the island. During 1940-75, average annual precipitation at Mineola and Riverhead (fig. 1) was $44 \mathrm{in} / \mathrm{yr}$. Approximately $21 \mathrm{in} / \mathrm{yr}$ is returned to the atmosphere through evapotranspiration, and about $1 \mathrm{in} / \mathrm{yr}$ is discharged to streams and tidewater as overland runoff. The remainder, about $22 \mathrm{in} / \mathrm{yr}$, infiltrates the land surface and recharges the underlying aquifer system (Cohen and others, 1968).

\section{Hydrogeology}

The lithology and water-bearing characteristics of the major hydrologic units are listed in table 1. Long Island's aquifer system can be characterized as an unconsolidated, southward-dipping, wedge-shaped unit containing three major aquifers and several confining units. The upper glacial (watertable) aquifer consists mainly of fine to coarse sand and gravel; its upper zone is the source of all dry-weather streamflow on the island. It is underlain by the Magothy aquifer, the source of most public-supply water, which is separated by the Raritan clay from the underlying Lloyd aquifer, a secondary source of public water. Beneath the Lloyd aquifer is crystalline bedrock, the base of the ground-water reservoir.

\section{Streamilow}

The stream channels on Long Island follow the remnants of a drainage pattern produced by meltwater from the Hisconsin Glaciation. The materials through which these channels course can be characterized as outwash in southern Long Island and as ice-contact deposits in the northern part of the island.

Most stream channels on Long Island are fairly straight, north-south trending channels that act as drains from the water table. The south-shore streams have longer channels and shallower gradients than the north-shore streams.

During dry weather, all streamflow is supplied by seepage from the upper part of the upper glacial aquifer. This seepage forms the major part of total stream discharge; under natural conditions it constitutes 95 percent of total annual streamflow (Pluhowski and Kantrowitz, 1964).

Most streamflow on Long Island remains fairly constant throughout the year and typically has variations of only a few cubic feet per second except during storms or periods of snowmelt. The largest stream studied is Nissequogue River, which has a long-term average annual discharge of 41.4 $\mathrm{ft} 3 / \mathrm{s}$; the smallest is Pines Brook, with an average annual discharge of 3.98 $\mathrm{ft}^{3} / \mathrm{s}$ (U.S. Geological Survey, 1979). 
Table 1.--Generalized description of geologic and hydrogeologic units, Long Island, New York.

[Modified from McClymonds and Franke, 1972]

\begin{tabular}{|c|c|c|c|}
\hline Series & Geologic unit & $\begin{array}{l}\text { Hydrogeologic } \\
\text { unit }\end{array}$ & $\begin{array}{l}\text { Lithology and water- } \\
\text { bearing characteristics }\end{array}$ \\
\hline \multirow[t]{2}{*}{ Pleistocene } & $\begin{array}{l}\text { Upper Pleistocene } \\
\text { deposits }\end{array}$ & Upper glacial & $\begin{array}{l}\text { Mainly sand and gravel } \\
\text { of moderate to high } \\
\text { permeability; also in- } \\
\text { cludes clayey till of } \\
\text { low permeability. }\end{array}$ \\
\hline & $\begin{array}{l}\text { Monmouth and Matawan } \\
\text { Groups, and Magothy } \\
\text { Formation, } \\
\text { undifferentiated. }\end{array}$ & Magothy aquifer & $\begin{array}{l}\text { Coarse to fine sand of } \\
\text { moderate permeability; } \\
\text { locally contains gravel } \\
\text { of high permeability } \\
\text { and abundant silt and } \\
\text { clay of low to very } \\
\text { low permeability. }\end{array}$ \\
\hline \multirow[t]{2}{*}{$\begin{array}{l}\text { Upper } \\
\text { Cretaceous }\end{array}$} & $\begin{array}{l}\text { Clay member of } \\
\text { Raritan Formation }\end{array}$ & Raritan clay & $\begin{array}{l}\text { Clay of very low per- } \\
\text { meability; some silt } \\
\text { and fine sand of low } \\
\text { permeability. }\end{array}$ \\
\hline & $\begin{array}{l}\text { Lloyd Sand Member } \\
\text { of Raritan Formation }\end{array}$ & Lloyd aquifer & $\begin{array}{l}\text { Sand and gravel of } \\
\text { moderate permeability; } \\
\text { some clayey material } \\
\text { of low permeability. }\end{array}$ \\
\hline
\end{tabular}

\section{URBAMIZATION}

\section{Population}

During the first two decades of this century, population growth on Long Island was greatest in Kings County. Queens County was largely suburban, and Nassau and Suffolk Counties were rural. In the $1920^{\circ} \mathrm{s}$ and $1930^{\circ} \mathrm{s}$, the main population growth was in Queens County and was accompanied by a moderate growth in industry.

Soon after World War II, population increased rapidly in westem Nassau County and expanded eastward until, by the mid-1950's, most of the county was urbanized. By the early $1960^{\circ} \mathrm{s}$, the population in western Suffolk County began a similar increase, which has continued at a moderate rate. Figure 2 depicts the increase in population density in selected townships and municipalities in Nassau County from 1920 to 1977; figure 3 depicts the growth in Suffolk. County. Table 2 gives the population figures for these townships and municipalities, in persons per square mile. 
POPULATION, IN PERSONS PER SQUARE MILE
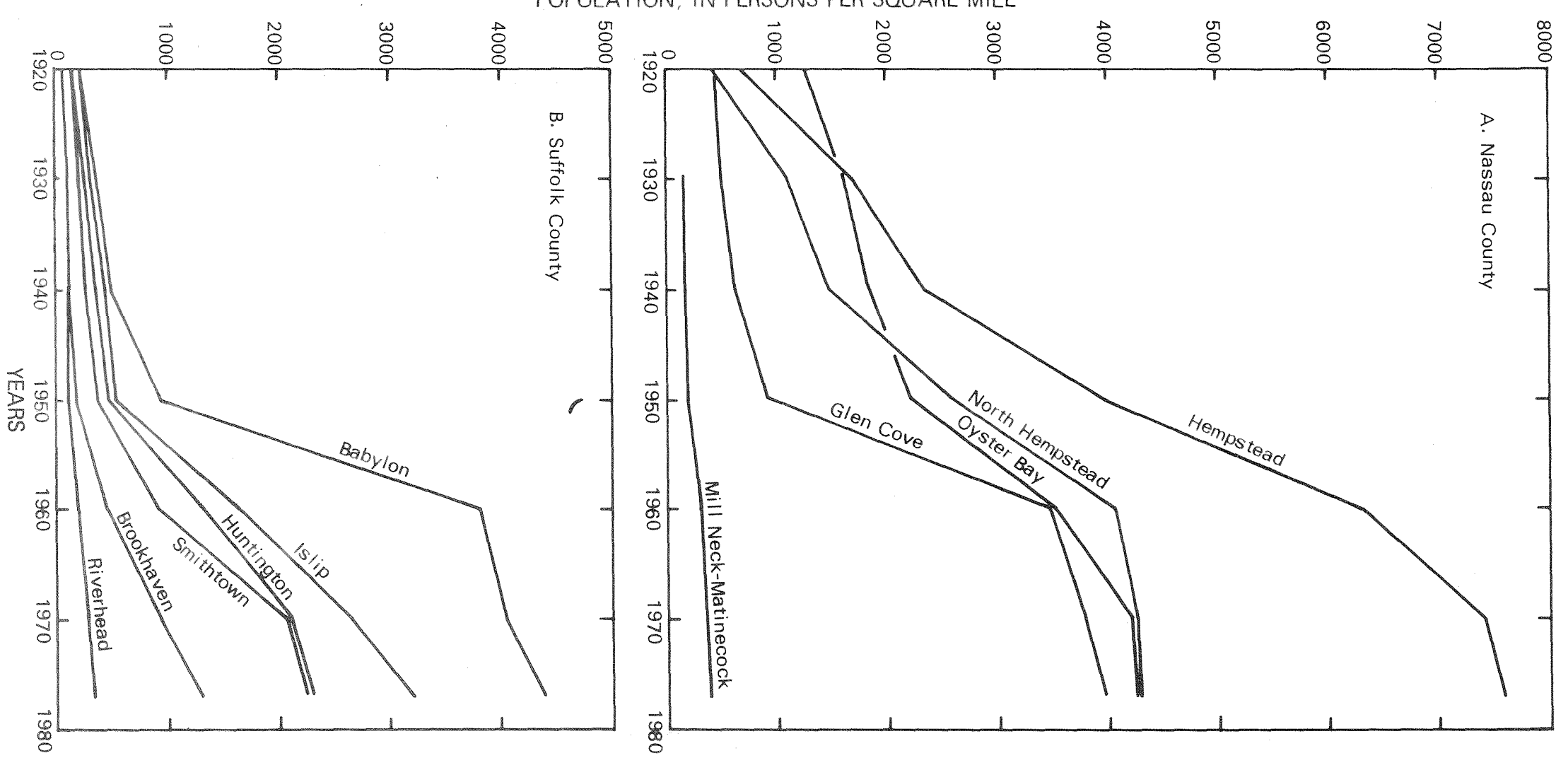

ERRATA

Water Resources Investigations 80-114

Page 4 second to last sentence should be "Figure 2 depicts the increase in population density in selected townships and municipalities in Nassau and Suffolk Counties." 


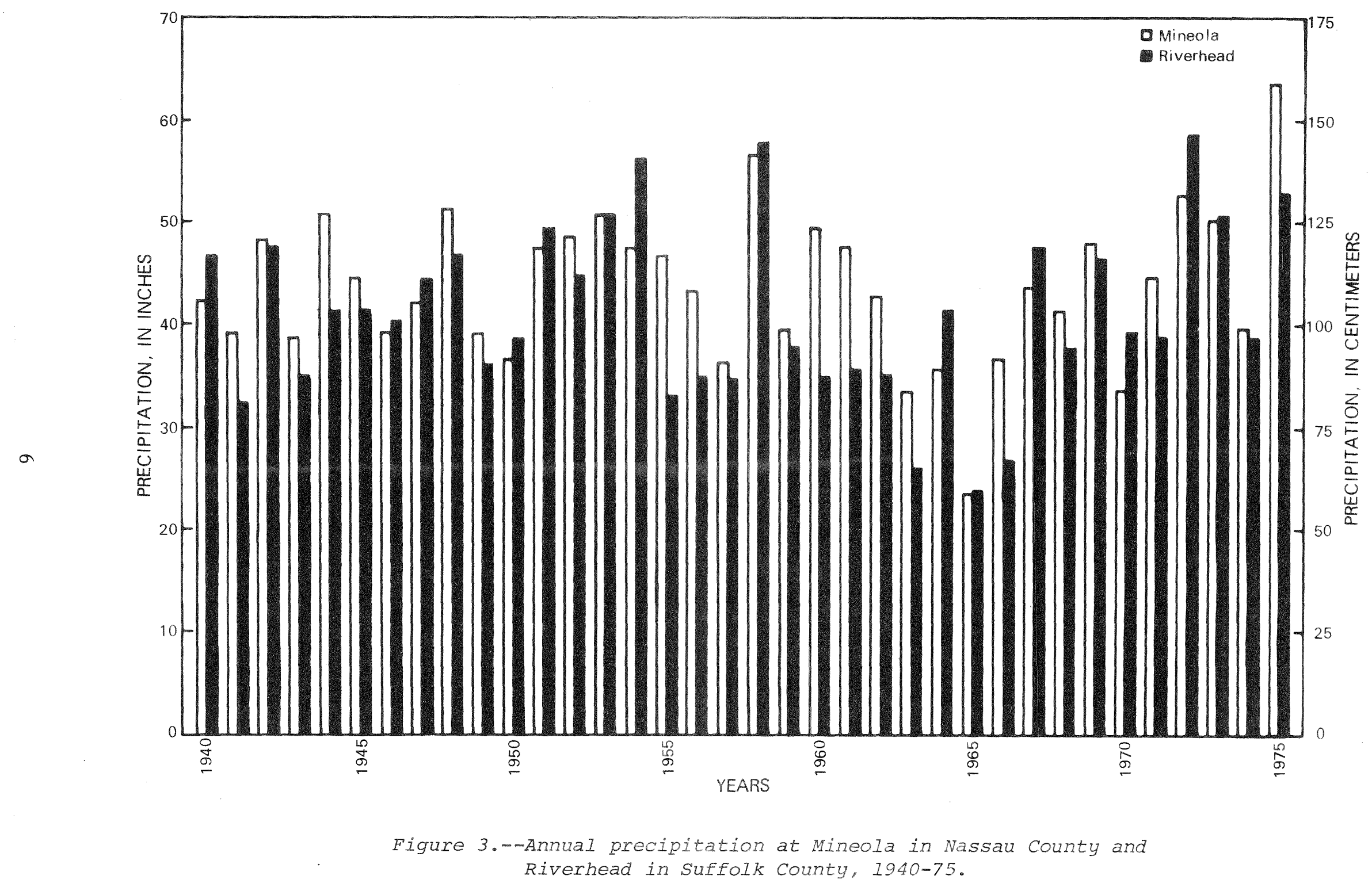


Suffolk County. Table 2 gives the population figures for these townships and municipalities, in persons per square mile.

Population growth and urbanization have been especially intense along the shores, although this is not apparent in figures 2 and 3 . The north shore of Nassau County is not developed uniformly because much of the land is occupied by 1 arge estates. This is illustrated by the contrast in the growth rates for Glen Cove and the villages of Mill Neck and Matinecock (table 2).

Land-use patterns in Nassau and Suffolk Counties have changed with urbanization. For example, Nassau County is nearly 50 percent residential, with a predominance of small lots of $1 / 4$ acre or less. Streets or highways and open or vacant land constitute an additional 40 percent, with the remaining 10 percent in recreational and institutional use (Cohen and others, 1968). In contrast, nearly 75 percent of the total area in Suffolk County is open or vacant (agricultural) land, and only about 15 percent is occupied by homes, streets, and parkways (Cohen and others, 1968). Most of this open land is at Suffolk's east end; the west end has become suburban.

Table 2.--Population density ${ }^{l}$ in Nassau and Suffolk Counties, 1950 and 1976.

[in persons per square mile]

\begin{tabular}{lccc}
\hline & 1950 & $\begin{array}{c}1976 \\
\text { (estimated) }\end{array}$ & Increase \\
\hline NASSAU COUNTY & & & \\
Glen Cove & 2,225 & 3,983 & 1,758 \\
North Hempstead & 2,650 & 4,442 & 1,792 \\
Hempstead & 4,000 & 7,599 & 3,599 \\
Oyster Bay & 938 & 4,236 & 3,298 \\
Mill Neck-Matinecock & 198 & 372 & 174 \\
SuFFolK CounTY & & & \\
Huntington & & & 1,792 \\
Babylon & 507 & 2,299 & 3,491 \\
Islip & 911 & 4,402 & 2,337 \\
Smithtown & 691 & 3,028 & 1,904 \\
Brookhaven & 390 & 2,294 & 1,083 \\
Riverhead & 170 & 1,253 & 268 \\
& 147 & 315 & \\
\hline
\end{tabular}

1 Population data from Long Island Lighting Co., 1976. Population was divided by area to obtain density. 


\section{Aquifor Rocharge}

As an area becomes urbanized, the construction of buildings, parking lots, roads, and other impermeable surfaces reduces recharge to underlying aquifers by preventing infiltration of precipitation. In central Nassau County and parts of Suffolk County, storm-water runoff is routed to recharge basins, where it infiltrates to the water table, so that the amount of recharge to the aquifers remains virtually unchanged (Seaburn and Aronson, 1974). However, in areas along the shore and near streams, runoff is routed directly to the streams and bays and is thus lost from the system.

Where sanitary sewer systems have not been constructed, ground water pumped for domestic use is returned to the aquifers as wastewater through cesspools and septic tanks, with only a small percentage lost to consumptive use. In such areas, fluctuations in ground-water levels are caused by natural variations in precipitation and evapotranspiration and are generally small, with no distinguishable long-term trends. Similarly, streamflow patterns show little change over time.

With the installation of sanitary sewers, a large component of recharge to the aquifer is lost as the wastewater is piped to treatment plants and out to sea. For example, discharge to the ocean from the Bay Park sewage-treatment plant in Nassau County increased by an order of magnitude from 1953-76, from 5.8 Mgal/day to $57.8 \mathrm{Mgal} /$ day (Sulam, 1979). Accordingly, ground water levels in the sewered area began to decline, and the length of wetted stream channels became shorter.

An additional loss of ground water in Nassau County results from the large ground-water withdrawals in adjacent Queens County. Ground-water levels in Queens have declined to such an extent that ground water now flows westward out of Nassau County at a greatly increased rate, causing ground-water levels and streamflow in Nassau County to decline considerably (Koszalka, 1975).

\section{METHOD OF STREAMFLOW ANALYSIS}

\section{Solvetion of Stroame}

Nine streams across Nassau and Suffolk Counties were chosen for study. These streams drain both the north and south shores of the island and are representative of the types of area under study. The streams were selected on the basis of length of record, completeness of record, and absence of artificial regulation. The streams are listed on page 9; their locations are shown in fig. 1 .

The period of record for these streams is generally continuous from the late $1930^{\circ} \mathrm{s}$ or early $1940^{\prime} \mathrm{s}$. Changes in streamflow patterns during the period of record were examined through flow-duration curves. Two 5-year time periods were selected for comparison, 1946-50 and 1970-74. The first interval represents conditions before urbanization became extensive in Nassau County; the second represents conditions after urbanization had become extensive throughout Nassau County and moderate in western Suffolk County. 
Glen Cove Creek at Glen Cove

01302500

Mil1 Neck Creek at Mil1 Neck

01303000

Nissequogue River at Smithtown

01304000

Carmans River at Yaphank

01305000

Connetquot River at Oakdale

01306500

Sampawams Creek at Babylon

01308000

Massapequa Creek at Massapequa

01309500

East Meadow Brook at Freeport

01310500

Pines Brook at Malverne

01311000

The selection of streams represents several stages of transition from rural to urban conditions. Pines Brook, East Meadow Brook, and Glen Cove Creek flow through areas of dense suburban to urban population centers that have been well established for the past few decades. These areas have also been served by sanitary sewers since the late $1950^{\circ} \mathrm{s}$ and early $1960^{\circ} \mathrm{s}$. Massapequa Creek, Sampawams Creek, and to a much lesser extent Mi11 Neck Creek flow through or are surrounded by moderate- to low-density suburban development with no sanitary sewers. Connetquot Brook, Nissequogue River, and Carmans River flow through rural areas of very little development.

To eliminate the possibility that dissimilar precipitation patterns might cause differences between flow patterns of the eastern and western streams, precipitation data collected and stored by the U.S. Geological Survey from Mineola in western Nassau. County and Riverhead in eastern Suffolk County were compared. Annual precipitation data from 1940 to 1975 are given in figure 3. These data indicate similar patterns of precipitation across the island, with total amounts in any given year differing by only a few inches. Annual average values of precipitation were compared and a $t-t e s t$ revealed no significant statistical difference between the precipitation values at the two locations for the years 1940-75.

Precipitation in each of the 5-year periods for the two stations was examined. Mineola in 1946-50 had a total precipitation of 208.48 inches with a mean of 41.70 inches and, during 1970-74, a total of 221.05 inches with a mean of 44.21 inches. Similarly, Riverhead during 1946-50 had a total precipitation of 205.87 inches with a mean of 41.17 and, during 1970-74, a total of 226.11 inches with a mean of 45.22 inches. The difference between the mean values of precipitation at Riverhead during the two periods was analyzed by a $t$-test, and no statistical difference was found at the 95-percent confidence level. 


\section{Flow-Duration Curves}

A flow-duration curve is a cumulative frequency curve that shows the percentage of time during which specified discharges were equaled or exceeded during a given time period. Its use is discussed in detail by Searcy (1959). The flow-duration curve applies only to the period for which data were analyzed. Although the curve does not show the chronologic sequence of flows, it provides a convenient means for studying the flow characteristics of streams and for comparing streams with one another.

The flow-duration curves were derived from dafly streamflow measurements collected by the U.S. Geological Survey since the early 1940's. To prepare the flow-duration curves in figures 4A-4I, daily flows during each of the two 5 -year perlods were arranged according to magnitude; percentage of time during which the flow equaled or exceeded the specified values was then computed. Thus, the curve represents an average for the period considered rather than the distribution of flow within a single year.

The shape of a flow-duration curve is determined by the geologic and hydrologic characteristics of the basin at the time represented by the data. A curve with a steep slope throughout denotes a highly variable stream whose flow is largely from direct runoff, whereas a curve with a relatively flat slope indicates a less variable discharge where ground-water seepage to the stream is the major source of streamflow. Under natural conditions, Long Island streams would be characterized by a curve with a relatively flat slope.

Two flow-duration curves were developed for each of the nine streams; one represents the years 1946-50, the other represents the years 1970-74. The curves for these two intervals provide a basis for comparison and evaluation of the effects of urbanization on streamflow. (See figs. 4A-4I.)

The upper end of the curve, the part above 2-percent duration, or discharge that was exceeded only 2 percent of the time, indicates the overland runoff component of the stream. A steep upper end indicates large volumes of water flowing into the stream during storms, whereas a flatter slope indicates a relatively minor contribution from overland runoff. Comparing this section of a curve for 1946-50 with that for 1970-74 indicates the extent to which storm runoff has increased stream discharge during peak flows.

The lower end of the curve indicates the low-flow characteristics of the stream and represents ground-water seepage. If the lower end of the curve has a shallow slope, the ground-water body supplies a consistent flow to the stream; if the curve is steep, the ground-water contribution is erratic and responds readily to variations in precipitation. Comparing the lower section of a curve for 1946-50 with that of 1970-74 indicates the extent to which lowered ground-water levels near the stream, such as from increased groundwater withdrawals or decreased recharge, have decreased the volume of ground water in storage available for streamflow. 

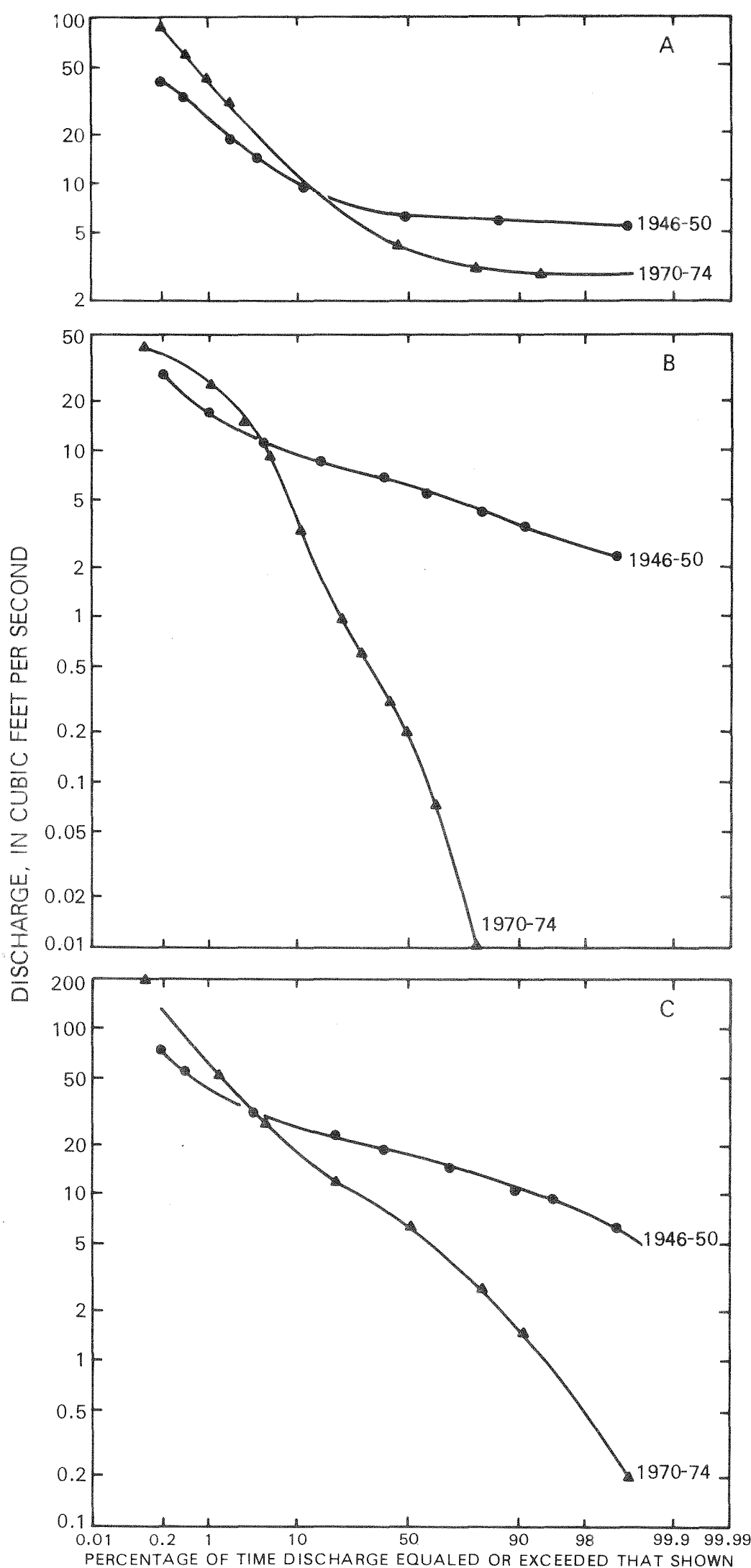

Figure 4.--Duration curves of daily flow, 1946-50 and 1970-74: $A$, Glen Cove Creek at Glen Cove; B, Pines Brook at Malverne; C, East Meadow Brook at Freeport. 

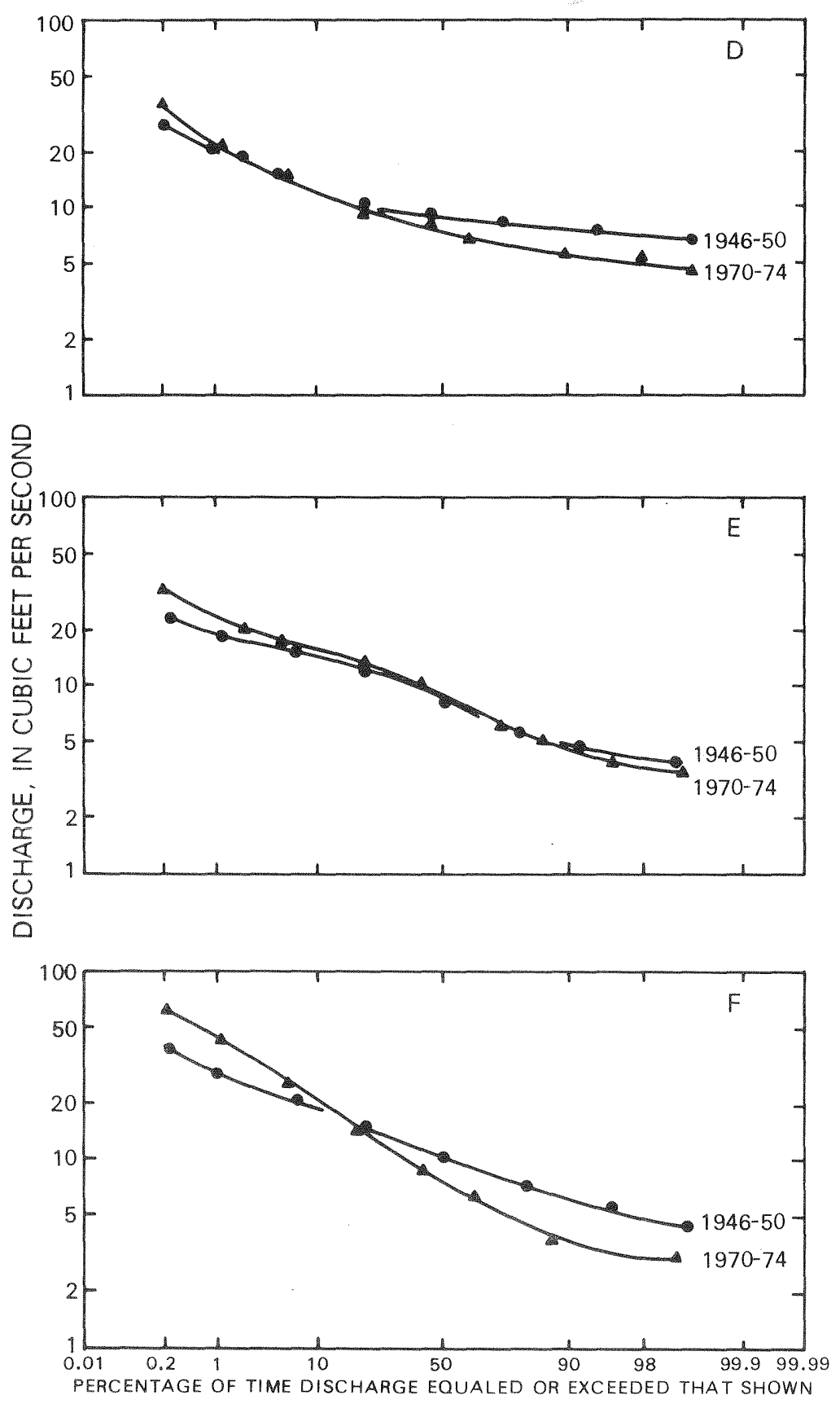

Figure 4 (Continued).--Duration curves of daily flow, 1946-50 and 1970-74: D, Mill Neck Creek at Mill Neck; E, Sampawans Creek at Babylon: $F$, Massapequa Creek at Massapequa. 

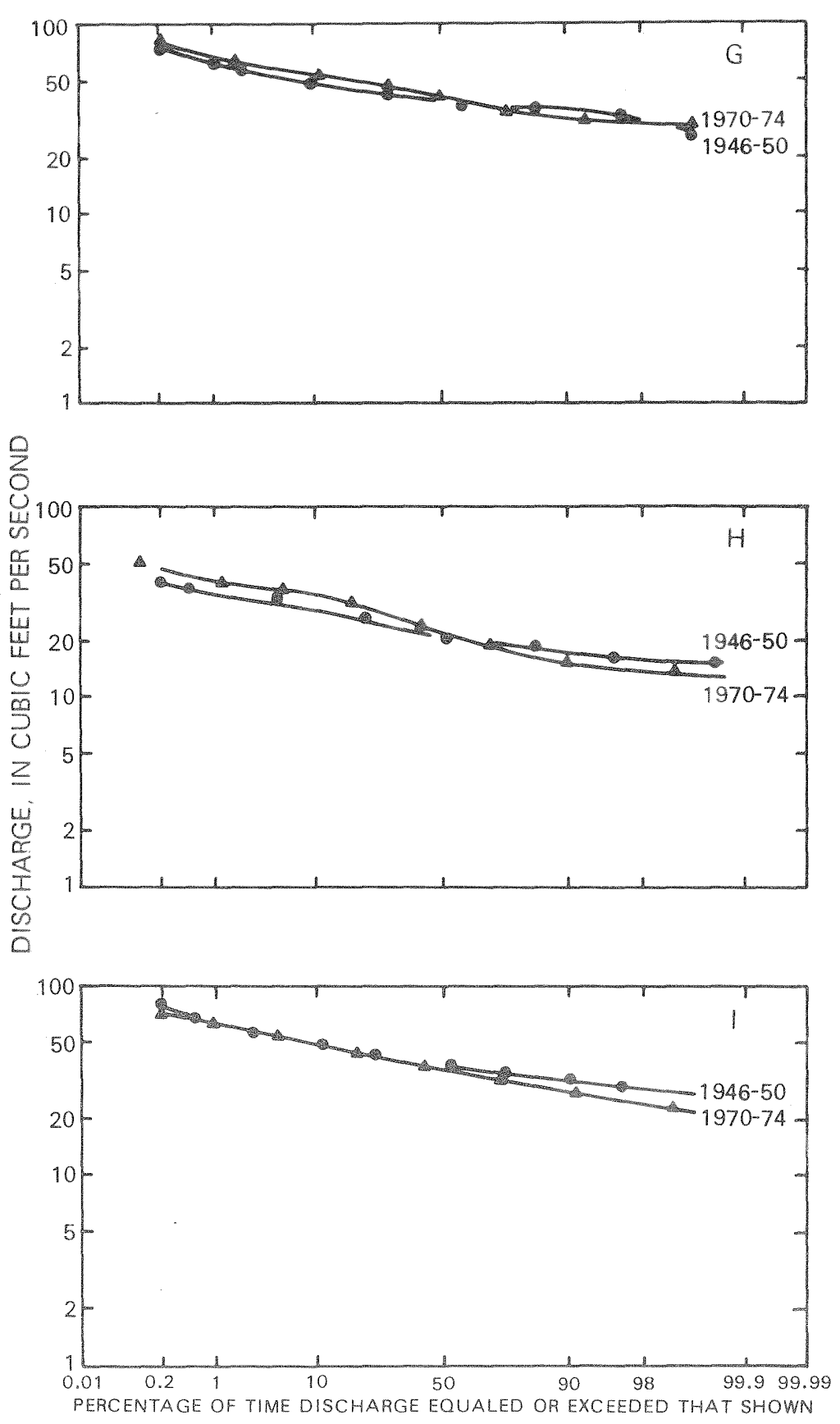

Figure 4 (Continued),-Duration curves of daily flow, 1946-50 and 1970-74: $G$, Nissequogue River near Smithtown: H, Camans River at Yaphank: I, Connetquot River near Oakdale. 


\section{PESULTS}

The shape of the flow-duration curves (figs. 4A-4I), and the streamflow data listed in table 3, indicate that streamflow patterns have changed in many of the streams studied since urbanization began. The streams that flow through heavily urbanized areas served by sanitary sewers show the largest changes.

The upper ends of the flow-duration curves for streams in areas of highest density (western Nassau County) are steeper and the maximum discharge values higher during $1970-74$ than during 1946-50, which indicates that larger percentages of total streamflow are now being contributed by surface runoff. The lower ends of the curves have also become steeper, which indicates smaller base flows as a result of lowered water levels in the sewered areas.

The nine streams can be grouped into three categories by degree of change in streamflow characteristics from 1946 to 1974. These categories correspond closely to the degree of urbanization in the vicinity of each group. Table 4 describes these three groups and gives the percentage change of peak flows and base flows since 1946.

The streams that show the maximum changes in streamflow are Glen Cove Creek, Pines Brook, and East Meadow Brook in Nassau County (figs. 4A-4C). Curves for these streams show increases in peak-flow discharges (1-percent duration) ranging from 41 to 65 percent from 1946 to 1974 (table 4), and lowflow decreases of at least 50 percent (at the 98-percent duration). These three streams flow through or border directly upon areas of dense population and areas where construction of sanitary sewers began in 1953 and was completed in the early $1960^{\circ} \mathrm{s}$.

The streams that show moderate changes in discharge are Mi11 Neck, Sampawams, and Massapequa Creeks in Nassau County ( $f i g s, 4 D-4 F$ ). This group shows 5-to 52-percent increases in peak flows (1-percent duration) and 10- to 36 -percent decreases in low flows (98-percent duration) from 1946 to 1974 (table 4). Sampawams and Massapequa Creeks flow through suburban areas that do not have sanitary sewers, and Mill Neck Creek flows through an area that has 1 ow population density but is apparently affected by the urbanized setting in nearby Glen Cove and Oyster Bay (table 2). Because ground-water levels have not declined as much in these areas as in the sewered areas, these streams are better able to sustain flow during extended periods of dry weather.

The streams that show only minor changes in streamflow are the Nissequogue, Carmans, and Connetquot Rivers in Suffolk County (figs. 4G-4I). These streams range from a 9-percent decrease to an 17 -percent increase in peak flow (1-percent duration) during the period studied and range from a 14 -percent decrease to a 7-percent increase in base flow (98-percent duration) (table 4). The curves for Nissequogue, Carmans, and Connetquot Rivers are relatively flat, indicating little contribution from direct runoff and wellsustained low flows during long periods of dry weather. Carmans River flows through an area that has experienced little growth in population density and therefore shows little change in streamflow. Both the Nissequogue River in 
Smithtown and the Connetquot River in Islip flow through areas experiencing sizeable population increases but show little or no change in flow characteristics. This would seem to contradict the above findings, except that both streams flow mostly through state parks where public access is restricted, activities are limited, and the streams have undergone no major changes in hydrologic regime. These park areas seem to buffer the impact of suburban development.

In general, the flow-duration curves for streams in highly urbanized and sewered areas have developed steep slopes and show large decreases in the low (base-flow) end of the curves, and streams in suburbanized, unsewered areas have shown moderate increases in slope. In contrast, areas that have not been suburbanized show 1ittle or no change in flow-duration curves from 1946 to 1974 and indicate how streamflow patterns on Long Island would be without man's influence.

\section{SUMMARY AND CONCLUSIONS}

Analysis of flow-duration curves for nine Long Island streams indicates that significant changes in the characteristics of streamflow correlate with the eastward population growth. In areas where population growth has been extensive since 1946, streamflow peaks have sharply increased, and low flow values have decreased. The greatest change in peak flow was at Glen Cove Creek in an urban, sewered area; flows at the 1-percent duration have increased by 65 percent. The largest decline in base flow was at Pines Brook, similarly located, where flow at the 60-percent duration has decreased by 99 percent. Flow at higher percentages of duration were zero.

Results of this study suggest that changes in streamflow patterns are largest in urbanized areas in which sanitary sewers have been installed. Streams in areas that are highly suburbanized but not yet sewered exhibit large increases in peak-flow discharge and small decreases in low-flow discharge; in both cases, changes are substantially less than those in the sewered areas.

Although Nissequogue and Connetquot Rivers flow through relatively urbanized areas, the streamflow patterns have not been significantly altered because the drainage areas include parks reserved for limited use, where the hydrologic system is relatively undisturbed.

Streamflow patterns of Carmans River, which flows through an area of relatively low population density, have changed little throughout the period examined. 
Tabie 3.--Stream discharge and percentage change from 1946-50 to 1970-74.

[Discharges are in cubic feet per second; stream locations are shown in fig. 1]

Percentage of time discharge was equaled or exceeded

\begin{tabular}{|c|c|c|c|c|c|c|c|c|c|c|c|c|c|c|}
\hline Stream Name & Period & 0.2 & 0.5 & 1 & 5 & 10 & 30 & 60 & 80 & 90 & 95 & 98 & 99 & 99.5 \\
\hline \multirow{2}{*}{ Glen Cove Creek } & $\begin{array}{l}1946-50 \\
1970-74 \\
\end{array}$ & $\begin{array}{l}40 \\
85 \\
\end{array}$ & $\begin{array}{l}33 \\
60 \\
\end{array}$ & $\begin{array}{l}26 \\
43 \\
\end{array}$ & $\begin{array}{l}12 \\
18 \\
\end{array}$ & $\begin{array}{l}9.7 \\
12 \\
\end{array}$ & $\begin{array}{l}8.5 \\
5.0 \\
\end{array}$ & $\begin{array}{l}6.1 \\
3.5 \\
\end{array}$ & $\begin{array}{l}5.9 \\
3.1 \\
\end{array}$ & $\begin{array}{l}5.8 \\
2.9 \\
\end{array}$ & $\begin{array}{l}5.7 \\
2.8 \\
\end{array}$ & $\begin{array}{r}5.7 \\
2.8 \\
\end{array}$ & $\begin{array}{l}5.7 \\
2.8 \\
\end{array}$ & $\begin{array}{l}5.7 \\
2.7 \\
\end{array}$ \\
\hline & $\begin{array}{l}\text { percent } \\
\text { change }\end{array}$ & 112 & 82. & 65 & 50 & 24 & -41 & -42 & -47 & -50 & -52 & -51 & -51 & -53 \\
\hline \multirow[t]{2}{*}{ Mill Neck Creek } & $\begin{array}{l}1946-50 \\
1970-74 \\
\end{array}$ & $\begin{array}{l}27 \\
35 \\
\end{array}$ & $\begin{array}{l}24 \\
31 \\
\end{array}$ & $\begin{array}{l}21 \\
22 \\
\end{array}$ & $\begin{array}{l}15 \\
15 \\
\end{array}$ & $\begin{array}{l}12.5 \\
12.5 \\
\end{array}$ & $\begin{array}{l}9.8 \\
8.7 \\
\end{array}$ & $\begin{array}{l}8.8 \\
7.0 \\
\end{array}$ & $\begin{array}{l}8.1 \\
6.1 \\
\end{array}$ & $\begin{array}{l}7.8 \\
5.5 \\
\end{array}$ & $\begin{array}{l}7.5 \\
5.3 \\
\end{array}$ & $\begin{array}{l}7.1 \\
5.0 \\
\end{array}$ & $\begin{array}{l}6.9 \\
5.8 \\
\end{array}$ & $\begin{array}{l}6.8 \\
5.6 \\
\end{array}$ \\
\hline & $\begin{array}{l}\text { percent } \\
\text { change }\end{array}$ & 30 & 30 & 5 & 0 & 0 & -11 & -20 & -25 & -30 & -29 & -30 & -16 & -18 \\
\hline \multirow[t]{2}{*}{ Nisseqrogue River } & $\begin{array}{l}1946-50 \\
1970-74 \\
\end{array}$ & $\begin{array}{l}80 \\
75 \\
\end{array}$ & $\begin{array}{l}72 \\
68 \\
\end{array}$ & $\begin{array}{l}68 \\
62 \\
\end{array}$ & $\begin{array}{l}59 \\
53 \\
\end{array}$ & $\begin{array}{l}55 \\
50 \\
\end{array}$ & $\begin{array}{l}47 \\
43 \\
\end{array}$ & $\begin{array}{l}38 \\
38 \\
\end{array}$ & $\begin{array}{l}35 \\
36 \\
\end{array}$ & $\begin{array}{l}33 \\
35 \\
\end{array}$ & $\begin{array}{l}32 \\
34\end{array}$ & $\begin{array}{l}30 \\
32 \\
\end{array}$ & $\begin{array}{l}29 \\
29 \\
\end{array}$ & $\begin{array}{l}28 \\
26\end{array}$ \\
\hline & $\begin{array}{l}\text { percent } \\
\text { change }\end{array}$ & -6 & -6 & -9 & -10 & -9 & -8 & 0 & 3 & 6 & 6 & 7 & 0 & -7 \\
\hline \multirow[t]{2}{*}{ Carmans River } & $\begin{array}{l}1946-50 \\
1970-74\end{array}$ & $\begin{array}{l}40 \\
47 \\
\end{array}$ & $\begin{array}{l}37 \\
44 \\
\end{array}$ & $\begin{array}{l}35 \\
41 \\
\end{array}$ & $\begin{array}{l}32 \\
37 \\
\end{array}$ & $\begin{array}{l}28 \\
34 \\
\end{array}$ & $\begin{array}{l}24 \\
27 \\
\end{array}$ & $\begin{array}{l}20 \\
20 \\
\end{array}$ & $\begin{array}{l}18 \\
17 \\
\end{array}$ & $\begin{array}{l}17 \\
15 \\
\end{array}$ & $\begin{array}{l}16 \\
14 \\
\end{array}$ & $\begin{array}{l}16 \\
14 \\
\end{array}$ & $\begin{array}{l}15 \\
13 \\
\end{array}$ & $\begin{array}{l}15 \\
13 \\
\end{array}$ \\
\hline & $\begin{array}{l}\text { percent } \\
\text { change }\end{array}$ & 18 & 19 & 17 & 16 & 21 & 12 & 0 & -6 & -12 & -12 & -12 & -13 & -13 \\
\hline \multirow{2}{*}{ Connetquot River } & $\begin{array}{l}1946-50 \\
1970-74\end{array}$ & $\begin{array}{l}78 \\
74\end{array}$ & $\begin{array}{l}70 \\
69\end{array}$ & $\begin{array}{l}65 \\
65\end{array}$ & $\begin{array}{l}55 \\
55\end{array}$ & $\begin{array}{l}49 \\
49\end{array}$ & $\begin{array}{l}42 \\
42\end{array}$ & $\begin{array}{l}36 \\
35\end{array}$ & $\begin{array}{l}33 \\
31\end{array}$ & $\begin{array}{l}31 \\
28\end{array}$ & $\begin{array}{l}30 \\
26\end{array}$ & $\begin{array}{l}28 \\
24\end{array}$ & $\begin{array}{l}27 \\
24\end{array}$ & $\begin{array}{l}26 \\
23\end{array}$ \\
\hline & $\begin{array}{l}\text { percent } \\
\text { change }\end{array}$ & -5 & -1 & 0 & 0 & 0 & 0 & -3 & -6 & -10 & -13 & -14 & -11 & -12 \\
\hline \multirow[t]{2}{*}{ Sampawarns Creek } & $\begin{array}{l}2146-50 \\
1970-74\end{array}$ & $\begin{array}{l}24 \\
33 \\
\end{array}$ & $\begin{array}{l}21 \\
27\end{array}$ & $\begin{array}{l}19 \\
24 \\
\end{array}$ & $\begin{array}{l}16 \\
17\end{array}$ & $\begin{array}{l}14 \\
16 \\
\end{array}$ & $\begin{array}{l}11 \\
12 \\
\end{array}$ & $\begin{array}{l}7.2 \\
7.4 \\
\end{array}$ & $\begin{array}{l}5.5 \\
5.5\end{array}$ & $\begin{array}{l}4.8 \\
4.7\end{array}$ & $\begin{array}{l}4.4 \\
4.2 \\
\end{array}$ & $\begin{array}{l}4.1 \\
3.7\end{array}$ & $\begin{array}{l}4.0 \\
3.6\end{array}$ & $\begin{array}{l}3.9 \\
3.5\end{array}$ \\
\hline & $\begin{array}{l}\text { percent } \\
\text { change }\end{array}$ & 38 & 28 & 26 & 6 & 14 & 9 & 3 & 0 & -2 & -4 & -10 & -10 & -10 \\
\hline \multirow[t]{2}{*}{ Massapequa Creek } & $\begin{array}{l}1946-50 \\
1970-74\end{array}$ & $\begin{array}{l}39 \\
61 \\
\end{array}$ & $\begin{array}{l}33 \\
51\end{array}$ & $\begin{array}{l}29 \\
44 \\
\end{array}$ & $\begin{array}{l}23 \\
27 \\
\end{array}$ & $\begin{array}{l}20 \\
21 \\
\end{array}$ & $\begin{array}{l}14 \\
12 \\
\end{array}$ & $\begin{array}{l}9.5 \\
6.2 \\
\end{array}$ & $\begin{array}{l}7.5 \\
4.5 \\
\end{array}$ & $\begin{array}{l}6.2 \\
3.7 \\
\end{array}$ & $\begin{array}{l}5.5 \\
3.4 \\
\end{array}$ & $\begin{array}{l}5.0 \\
3.2 \\
\end{array}$ & $\begin{array}{l}4.8 \\
3.1 \\
\end{array}$ & $\begin{array}{l}4.5 \\
3.1 \\
\end{array}$ \\
\hline & $\begin{array}{l}\text { percent } \\
\text { change }\end{array}$ & 56 & 54 & 52 & 17 & 5 & -14 & -35 & -40 & -40 & -38 & -36 & -35 & -31 \\
\hline \multirow[t]{2}{*}{ East Meadow Brook } & $\begin{array}{l}1946-50 \\
1970-74\end{array}$ & $\begin{array}{r}75 \\
130 \\
\end{array}$ & $\begin{array}{l}54 \\
88\end{array}$ & $\begin{array}{l}44 \\
62\end{array}$ & $\begin{array}{l}30 \\
27\end{array}$ & $\begin{array}{l}26 \\
18 \\
\end{array}$ & $\begin{array}{c}21 \\
9.7\end{array}$ & $\begin{array}{c}17 \\
5.2 \\
\end{array}$ & $\begin{array}{c}13 \\
2.8 \\
\end{array}$ & $\begin{array}{l}12 \\
1.6 \\
\end{array}$ & $\begin{array}{l}9.5 \\
0.95 \\
\end{array}$ & $\begin{array}{l}8.0 \\
0.50 \\
\end{array}$ & $\begin{array}{l}6.9 \\
0.31 \\
\end{array}$ & $\begin{array}{l}5.8 \\
0.20\end{array}$ \\
\hline & $\begin{array}{l}\text { percent } \\
\text { change }\end{array}$ & 73 & 63 & 41 & -10 & -31 & -53 & -69 & -78 & -87 & -90 & -94 & -96 & -97 \\
\hline \multirow{2}{*}{ Pines Brook } & $\begin{array}{l}1946-50 \\
1970-74\end{array}$ & $\begin{array}{l}28 \\
38\end{array}$ & $\begin{array}{l}21 \\
32\end{array}$ & $\begin{array}{l}17 \\
26\end{array}$ & $\begin{array}{l}11 \\
10\end{array}$ & $\begin{array}{l}9.5 \\
3.3\end{array}$ & $\begin{array}{l}7.4 \\
0.58\end{array}$ & $\begin{array}{l}5.5 \\
0.08\end{array}$ & $\begin{array}{l}4.2 \\
0\end{array}$ & 3.5 & $\begin{array}{l}3.0 \\
0\end{array}$ & $\begin{array}{l}2.6 \\
0\end{array}$ & $\begin{array}{l}2.4 \\
0\end{array}$ & $\begin{array}{l}2.3 \\
0\end{array}$ \\
\hline & $\begin{array}{l}\text { percent } \\
\text { change }\end{array}$ & 36 & 52 & 53 & -9 & -65 & -92 & -99 & -100 & -100 & -100 & -100 & -100 & -100 \\
\hline
\end{tabular}


Table 4.--Changes in stream discharge and population density in surrounding communities, Nassau and Suffolk Counties, 1946-74.

[Discharge is in cubic feet per second; locations are shown in fig. 1]

\begin{tabular}{|c|c|c|c|c|}
\hline Stream name & $\begin{array}{l}\text { Percentage change } \\
\text { at } 1 \text {-percent } \\
\text { flow duration } \\
\text { (peak flow) }\end{array}$ & $\begin{array}{l}\text { Percentage change } \\
\text { at 98-percent } \\
\text { flow duration } \\
\text { (base flow) }\end{array}$ & $\begin{array}{l}\text { Change in popula- } \\
\text { tion density } \\
\text { (persons per mi2) }\end{array}$ & $\begin{array}{l}\text { Surrounding } \\
\text { community }\end{array}$ \\
\hline \multicolumn{5}{|l|}{ Nassau County } \\
\hline East Meadow Brook (south shore) & 41 & -94 & 3599 & Hempstead \\
\hline Glen Cove Creek (north shore) & 65 & -51 & $1758 / 3298$ & Glen Cove/Oyster Bay \\
\hline Pines Brook (south shore) & 53 & -100 & 3599 & Hempstead \\
\hline Massapequa Creek (south shore) & 52 & -36 & 3298 & Oyster Bay \\
\hline Mill Neck Creek (north shore) & 5 & -30 & 174 & Mill Neck-Matinecock \\
\hline Sampawams Creek (south shore) & 26 & -10 & $3491 / 2337$ & Babylon/Islip \\
\hline \multicolumn{5}{|l|}{ Suffolk County } \\
\hline Carmans River (south shore) & 17 & -12 & 1083 & Brookhaven \\
\hline Connetquot River (south shore) & 0 & -14 & $2 / 2337$ & Islip \\
\hline Nissequogue River (north shore) & -9 & 7 & $2 / 1904$ & Smithtown \\
\hline
\end{tabular}

1 Data from Long Island Lighting Company population survey, 1976.

2 Streams flow through undeveloped parklands. 


\section{REFERENCES CITED}

Cohen, Philip, Franke, O. L., and Foxworthy, B. L., 1968, An Atlas of Long Island's water resources: New York Water Resources Commission Bulletin $62,117 \mathrm{p}$.

Franke, 0. L., 1968, Double-mass curve analysis of the effects of sewering on ground-water levels on Long Island, New York, in Geological Survey research, 1968: U.S. Geological Survey Professional Paper 600-B, p. B 205-B209.

Garber, M. S., and Sulam, D. J., 1976, Factors affecting declining water levels in a sewered area of Nassau County, New York: U. S. Geological Survey Journal of Research, vol. 4, no. 3, p. 255-265.

Kimme1, G. E., and Harbaugh, A. W., 1975, Analog-model analysis of hydrologic effects of sewerage in southeast Nassau and southwest Suffolk Counties, Long Island, New York: U.S. Geological Survey Open-File Report 75-535, $22 \mathrm{p}$.

Kimme1, G. E., 1976, Analog-model analysis of effects of waste-water management on the ground-water reservoir in Nassau and Suffolk Counties, New York--Report 1. Proposed and current sewerage: U.S. Geological Survey Open-File Report 76-441, 32 p.

Kimme1, G. E., Ku, H. F. H., Harbaugh, A. W., Sulam, D. J., and Getzen, R. T•, 1977. Analog model prediction of the hydrologic effects of sanitary sewerage in southeast Nassau and southwest Suffolk Counties, New York: Nassau County Department of Public Works, Long Island Water Resources Bulletin LIWR $-6,25 \mathrm{p}$.

Koszalka, E. J., 1975, The water table on Long Island, New York, in March 1974: Long Island Water Resources Bulletin 5, 7 p.

McClymonds, N. E., and Franke, O. L., 1972, Water-transmitting properties of Long Island's aquifers: U.S. Geological Survey Professional Paper 627-E, $24 \mathrm{p}$.

Long Island Lighting Company, 1976, Population Survey, Long Island Lighting Company, $48 \mathrm{p}$.

Pluhowski, E. J., and Kantrowitz, I. H., 1964, Hydrology of the Babylon Islip area, Suffolk County, Long Island, New York: U.S. Geological Survey Wa ter-Supply Paper 1785, 119 p.

Pluhowski, E. J., and Spinel1o, A. G., 1978, Impact of sewage systems on stream base flow and ground-water recharge on Long Island, New York: U.S. Geological Survey Journal of Research 6, no. 2, p. 263-271.

Seaburn, G. E., and Aronson, D. A., 1974, Influence of recharge basins on the hydrology of Nassau and Suffolk Counties, Long Island, New York: U.S. Geological Survey Water-Supply Paper 2031, 66 p. 


\section{REFERENCES CITED (continued)}

Searcy, J. K., 1959, Flow-duration curves: U. S. Geological Survey WaterSupply Paper 1542-A, 33 p.

Sulam, D. J., 1979, Analysis of changes in ground-water levels in a sewered and an unsewered area of Nassau County, Long Island, New York, Ground Water, 17, no. 5, p. 446-455.

U.S. Geological Survey, 1979, Water resources data for New York, Water Year 1978, Volume 2.--Long Island: U.S. Geological Survey Water Data Rept. NY 78-2, 264 p. (issued annually). 
